\title{
The genetic epidemiology of idiopathic scoliosis
}

\author{
Kristen Fay Gorman · Cédric Julien · Alain Moreau
}

Received: 2 December 2011/Revised: 17 May 2012/Accepted: 22 May 2012/Published online: 14 June 2012

(C) The Author(s) 2012. This article is published with open access at Springerlink.com

\begin{abstract}
Purpose Idiopathic scoliosis is a complex developmental syndrome defined by an abnormal structural curvature of the spine. High treatment costs, chronic pain/discomfort, and the need for monitoring at-risk individuals contribute to the global healthcare burden of this musculoskeletal disease. Although many studies have endeavored to identify underlying genes, little progress has been made in understanding the etiopathogenesis. The objective of this comprehensive review was to summarize genetic associations/linkages with idiopathic scoliosis, as well as explore the strengths and weaknesses of each study, such that it may serve as a guide for the design and interpretation of future genetic studies in scoliosis.

Methods We searched PubMed and Human Genome Epidemiology (HuGE) Navigator using the search terms "gene and scoliosis". Linkage or association studies published in English and available full-text were further analyzed as regards results, experimental design, and statistical approach.

Results We identified and analyzed 50 studies matching our criteria. These consisted of 34 candidate gene studies (6 linkage, 28 association) and 16 genome-wide studies
\end{abstract}

K. F. Gorman · C. Julien · A. Moreau ( $\square)$

Viscogliosi Laboratory in Molecular

Genetics of Musculoskeletal Diseases, Sainte Justine

University Hospital Research Center, Montreal, QC, Canada

e-mail: alain.moreau@ recherche-ste-justine.qc.ca

K. F. Gorman · C. Julien · A. Moreau

Department of Biochemistry, Faculty of Medicine,

University of Montreal, Montreal, QC, Canada

A. Moreau

Department of Stomatology, Faculty of Dentistry,

University of Montreal, Montreal, QC, Canada
[14 pedigree-based linkage, 2 genome-wide association studies (GWAS)]. Findings involved genes related to connective tissue structure, bone formation/metabolism, melatonin signaling pathways, puberty and growth, and axon guidance pathways. Variability in results between studies suggested ethnic and/or genetic heterogeneity.

Conclusions The major difficulty in idiopathic scoliosis research is phenotypic and genetic heterogeneity. Genetic research was overrepresented by underpowered studies. The use of biological endophenotypes, as well as restricted clinical definitions, may help to partition variation and increase the power of studies to detect or confirm an effect.

Keywords Genetics - Genes - Epidemiology ·

Idiopathic scoliosis - Adolescent idiopathic scoliosis .

Spinal curvatures

\section{Introduction}

Idiopathic scoliosis (IS) is a complex developmental syndrome that constitutes the largest subgroup of human spinal curvatures [Online Mendelian Inheritance in Man (OMIM): 181800]. First described by Hippocrates in On the Articulations (Part 47), IS has been the subject of ongoing research, and yet its etiology remains enigmatic. IS is marked by phenotypic complexity (variations in curve morphology and magnitude, age of onset, rate of progression), and a prognosis ranging from increase in curve magnitude, to stabilization, or to resolution with growth. Genetic factors are known to play a role, as observed in twin studies and singleton multigenerational families [1]. A recent study of monozygotic and dizygotic twins from the Swedish twin registry estimated that overall genetic effects accounted for $38 \%$ of the observed phenotypic variance, leaving the remaining $62 \%$ 
to environmental influences [2]. Genetic complexity in IS is further inferred from inconsistent inheritance [3-6], discordance among monozygotic twins [7-9], and highly variable results from genetic studies.

The standard of care for scoliosis has not changed significantly in the past three decades, from initiating observation to bracing and to spinal fusion surgery as a last resort [10]. The healthcare costs of bracing, hospitalization, surgery, and chronic back pain are substantial. An understanding of the genetics underlying the disorder would help lead to earlier diagnosis, identification of at-risk individuals, and more effective preventive and/or therapeutic choices.

Genetic variants that can affect a person's predisposition to spinal curvature and the propensity for progression to severe curvature are still unknown. Since 1992, over 60 studies have attempted to identify genes by either genomewide or hypothesis-driven designs, using either pedigrees (linkage analysis) or unrelated case-control population samples (association studies). Of over 30 candidate genes tested, 18 unique loci have been identified, suggesting that IS may be caused by multiple genes segregating differently in various populations. The goal of this review was to evaluate the various genetic studies and amalgamate their results to provide new insights. As reviewing genetic studies in a complex syndrome such as IS requires an evaluation of study design, and not merely a reporting of the findings [11], this comprehensive review may also serve as a guide for the design and interpretation of future genetic studies in IS [12].

\section{Methods}

We conducted a literature search of the PubMed database using the term "gene and scoliosis" to retrieve genetic studies in IS published between 1992 and 2011. Studies published in English and available as full-text were considered for further analysis if they referred to either association or linkage studies. The search was replicated using Human Genome Epidemiology (HuGE) Navigator, version 2.0 [13].

We evaluated the quality of the experimental design as follows: For association studies, we examined the number of individuals included (case and control groups), whether/how the phenotype was defined (female only, gendermatched, gender not defined; minimum curve magnitude considered; whether the phenotype was subcategorized; whether the phenotype was confirmed by physical examination, radiograph, or questionnaire), and the statistics employed (correction for multiple testing when appropriate; power analysis when appropriate). For linkage studies, we considered the number and size of families, how the phenotype was defined, the design of the study (parametric or nonparametric analysis), and the strength of the linkage.

\section{Results}

We found 50 articles that matched our criteria. These consisted of 34 candidate gene studies (6 linkage studies and 28 association studies) as well as 16 genome-wide studies [14 pedigree-based linkage studies and 2 genomewide association studies (GWAS)]. Nine other candidate gene studies were not considered for analysis because they did not satisfy inclusion criteria (were not published in English or available as full text articles). A yearly breakdown of all studies identified is shown in Fig. 1.

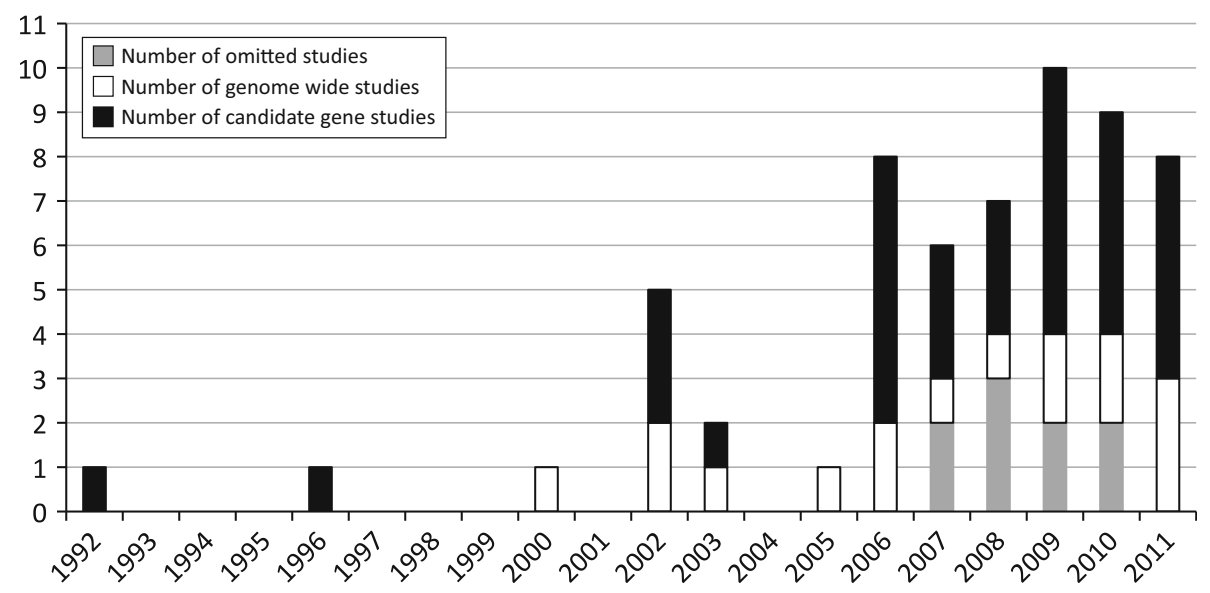

Fig. 1 Survey of genetic studies in idiopathic scoliosis. Efforts to identify genes for idiopathic scoliosis have largely been hypothesisdriven candidate gene studies, the majority of which were association studies. Year-by-year results are shown. Most of the genome-wide studies were linkage studies. Genome-wide studies do not presume a hypothesis to locate associated or linked chromosomal regions, while candidate gene studies examine the effects of specific gene variants hypothetically involved in the disease. Candidate gene studies are shown in black $(n=34)$, genome-wide studies in white $(n=16)$; studies not analyzed in this review are shown in gray $(n=9)$ 


\section{Candidate gene studies}

The selection of candidate genes for study can be made based on biological systems possibly playing a role in the etiopathogenesis of a disorder (from clinical evaluations or animal research), previous genetic studies showing an association (replication studies), or positional information gained from linkage studies (in combination with hypotheses). Between 1992 and 2006, many candidate gene studies for IS were family-based linkage studies [14-19]. Whereas family-based methods of hypothesis testing are more efficient at finding variants underlying rare conditions or rare subphenotypes of a common condition [20], they have largely been abandoned in the study of complex diseases due to their low power for detecting common variants [21, 22]. This may explain why, after 2006, casecontrol association studies constituted the bulk of candidate gene research.

For the included studies, we subdivided candidate genes by category reflecting their hypothetical functional involvement in IS: connective tissue structure, bone formation and bone metabolism, melatonin signaling pathway, and puberty and growth (Table 1).

Studies tested for correlations to curve predisposition, progression (severity), and in some cases, comorbidities such as low bone mineral density or abnormal anthropometric features. From the studies listed in Table 1, we highlighted genetic regions associated/linked to IS (Table 2) and provided details of polymorphisms for which no association was detected (Table 3 ).

\section{Connective tissue structure}

Structural proteins are those involved in the extracellular matrix. The genes encoding fibrillin $(F B N 1)$, elastin $(E L N)$, collagen I A1 and A2 (COL1A1, COL1A2), collagen II A1 (COL2A1), and aggrecan (ACAN), showed no association with IS on linkage analysis and/or transmission disequilibrium testing [14-16, 18]. Interestingly, using 50 informative Italian trios, Montanaro and colleagues [19] showed that an intragenic microsatellite (short tandem repeat) polymorphism in the $3^{\prime}$ untranslated region of the matrilin 1 gene (MATN1) was associated with adolescent IS. Matrilin 1 is a non-collagenous protein, also known as cartilage matrix protein; it is involved in extracellular matrix assembly and is essential for support of the spine [20]. Further to these results, Chen et al. demonstrated a similar association in a Chinese population sample (419 cases/750 controls), using tag single nucleotide polymorphisms (SNPs) from the HapMap database [21, 22]. The association, however, could not be detected in a larger Japanese cohort (789 cases/1,239 controls) even though the study was sufficiently powered [23]. Based on smaller cohorts, the earlier MATN1 results may likely be false positives rather than differences related to genetic heterogeneity between populations.

Human lysyl oxidases are enzymes involved in the modeling of collagen and elastin. Despite prior experiments in animal models suggesting a link to scoliosis, no association was found for five genes ( $L O X, L O X 1, L O X 2$, $L O X 3, L O X 4$ ) when common polymorphisms were verified in an American population (discovery cohort 138 cases/411 controls, replication cohort 400 cases/506 controls) [24].

Extracellular matrix degradation and remodeling are important for normal endochondral ossification. The process is mainly regulated by matrix metalloproteinases (MMPs) and their inhibitors (tissue inhibitors of metalloproteinases, TIMPs) $[25,26]$. TIMP2 is the major TIMP expressed during endochondral ossification and has the capacity to inhibit a broad range of MMPs [27, 28]. The TIMP2 gene is located at $17 \mathrm{q} 25.3$, a region previously identified as linked to IS [29]. A polymorphism in the TIMP2 promoter was indeed associated with thoracic curve severity $(n=354)$, though not with lumbar curve severity $(n=216)$ or curve predisposition, in a cohort of Chinese females (570 cases/210 controls) [30]. MMP3 was correlated to curve predisposition in a small Italian cohort (53 cases/206 controls) [31], but not in a larger Chinese cohort (487 cases/494 controls) [32]. Nor was MMP3 directly associated with IS in a Hungarian sample (126 cases/197 controls), although the authors suggested that MMP3 might modulate curve susceptibility when interacting with bone morphogenetic protein 4 (BMP4) [33].

Dipeptidyl-peptidase 9 (DPP9) is a widely expressed gene coding for a protease that functions in cell adhesion, migration, and apoptosis [34]. Based on its location at 19p13.3, a region identified as linked to IS in two linkage studies [35, 36], it was tested as a candidate in Chinese females (571 cases/236 controls). No association was detected [37].

To summarize, of the structural genes tested, TIMP2 was positively associated with thoracic curve severity in a Chinese cohort. These results need to be replicated using an independent cohort, especially as certain associations such as MATN1 or MMP3 were not replicated using larger cohorts. Furthermore, the linkage and transmission disequilibrium studies that showed negative results may have been underpowered to detect common variants possibly associated with IS, so those genes cannot be ruled out in the general population. Nonetheless, the study showing a negative association between the five lysyl oxidase genes and IS had $80 \%$ power to detect an odds ratio of 1.7-2.0, assuming a dominant model of inheritance with no additive or multiplicative effects, a prevalence in the population of $3 \%$, and a minor allele frequency of 0.10 [24]. 
Table 1 Candidate gene studies for idiopathic scoliosis
Some studies tested for multiple candidate genes. Therefore, the number of inquiries, as shown here, exceeded the number of association studies. The number of positive or negative associations reflects the inquiry conclusions, based on the $p$ values reported. Among the 61 inquiries that matched inclusion criteria, 18 showed positive associations with idiopathic scoliosis. RORA was evaluated in one study [63], but no polymorphisms were found *One study for IL6 [32] was inconclusive, as the single nucleotide polymorphism verified was not polymorphic in the study cohort

\begin{tabular}{|c|c|c|c|}
\hline Gene & $\begin{array}{l}\text { Number of } \\
\text { inquiries }\end{array}$ & $\begin{array}{l}\text { Number of positive } \\
\text { associations } \\
\text { [References] }\end{array}$ & $\begin{array}{l}\text { Number of negative } \\
\text { associations } \\
\text { [References] }\end{array}$ \\
\hline \multicolumn{4}{|l|}{ Connective tissue structure } \\
\hline FBN1 & 1 & 0 & $1[14]$ \\
\hline ELN & 1 & 0 & $1[14]$ \\
\hline COL1A1 & 1 & 0 & $1[14]$ \\
\hline COL1A2 & 2 & 0 & $2[14,15]$ \\
\hline COL2A1 & 1 & 0 & $1[14]$ \\
\hline ACAN & 2 & 0 & $2[16,18]$ \\
\hline MATN1 & 3 & $2[19,22]$ & $1[23]$ \\
\hline LOX1, LOX2, LOX3, LOX4, LOX5 & 1 & 0 & $1[24]$ \\
\hline TIMP2 & 1 & $1[30]$ & 0 \\
\hline MMP3 & 3 & $1[31]$ & $2[32,33]$ \\
\hline DPP9 & 1 & 0 & $1[37]$ \\
\hline \multicolumn{4}{|l|}{ Bone formation/metabolism } \\
\hline BMP4 & 1 & 0 & $1[33]$ \\
\hline LEP & 1 & 0 & $1[33]$ \\
\hline CALM1 & 1 & $1[45]$ & 0 \\
\hline IL6 & 4 & $2[31,52]$ & $1[33]^{*}$ \\
\hline VDR & 2 & $1[53]$ & $1[54]$ \\
\hline TNFRSF11B (OPG) & 1 & $1[55]$ & 0 \\
\hline RANKL & 1 & 0 & $1[55]$ \\
\hline RANK & 1 & 0 & $1[55]$ \\
\hline \multicolumn{4}{|l|}{ Melatonin signaling pathway } \\
\hline MTNR1A & 3 & 0 & $3[17,59,60]$ \\
\hline MTNR1B & 6 & $1[62]$ & $5[23,33,60,61,63]$ \\
\hline TPH1 & 3 & $1[64]$ & $2[23,60]$ \\
\hline ASMT (HIOMT) & 1 & 0 & $1[60]$ \\
\hline AANAT (SNAT) & 2 & 0 & $2[60,64]$ \\
\hline GPR50 & 1 & 0 & $1[63]$ \\
\hline \multicolumn{4}{|l|}{ Puberty and growth } \\
\hline CYP17 & 1 & 0 & $1[54]$ \\
\hline ESR1 (alpha) & 6 & $4[45,67-69]$ & $2[70,71]$ \\
\hline ESR2 (beta) & 2 & $1[73]$ & $1[71]$ \\
\hline GPER (GPR30) & 1 & $1[74]$ & 0 \\
\hline GHR & 2 & 0 & $3[76,78]$ \\
\hline IGF1 & 3 & 1 [77] & $2[23,78]$ \\
\hline
\end{tabular}

Bone formation and bone metabolism

Other IS candidate genes are related to bone integrity and formation. Bone morphogenetic proteins are polypeptide growth factors that enhance the differentiation of osteoblasts [38]. BMP4 is able to stimulate de novo bone and cartilage formation [39, 40]. Thus BMP4 was tested in a Hungarian sample (reference SNP rs4898820) (126 cases/ 197 controls); no association with IS was found [33]. The group also tested a SNP in the leptin gene (LEP) (rs7799039) and found that although it was not directly associated with IS, it may interact with the gene for interleukin-6 (IL6) to cause IS. However, no correction for multiple testing was performed in this study. The same group also tested the gene encoding calmodulin 1 (CALM1), a calcium-dependent regulatory protein that mediates a large number of proteins and plays a key role in the regulation of bone turnover [41]. CALM1 had been hypothesized to play a role in IS pathogenesis [42-44]. In a small Chinese sample (67 cases/100 controls), polymorphisms in rs12885713 were found to be associated with the predisposition for a double curve [45].

Generalized low bone mass and osteopenia in the axial and peripheral skeleton have been described in IS, along 


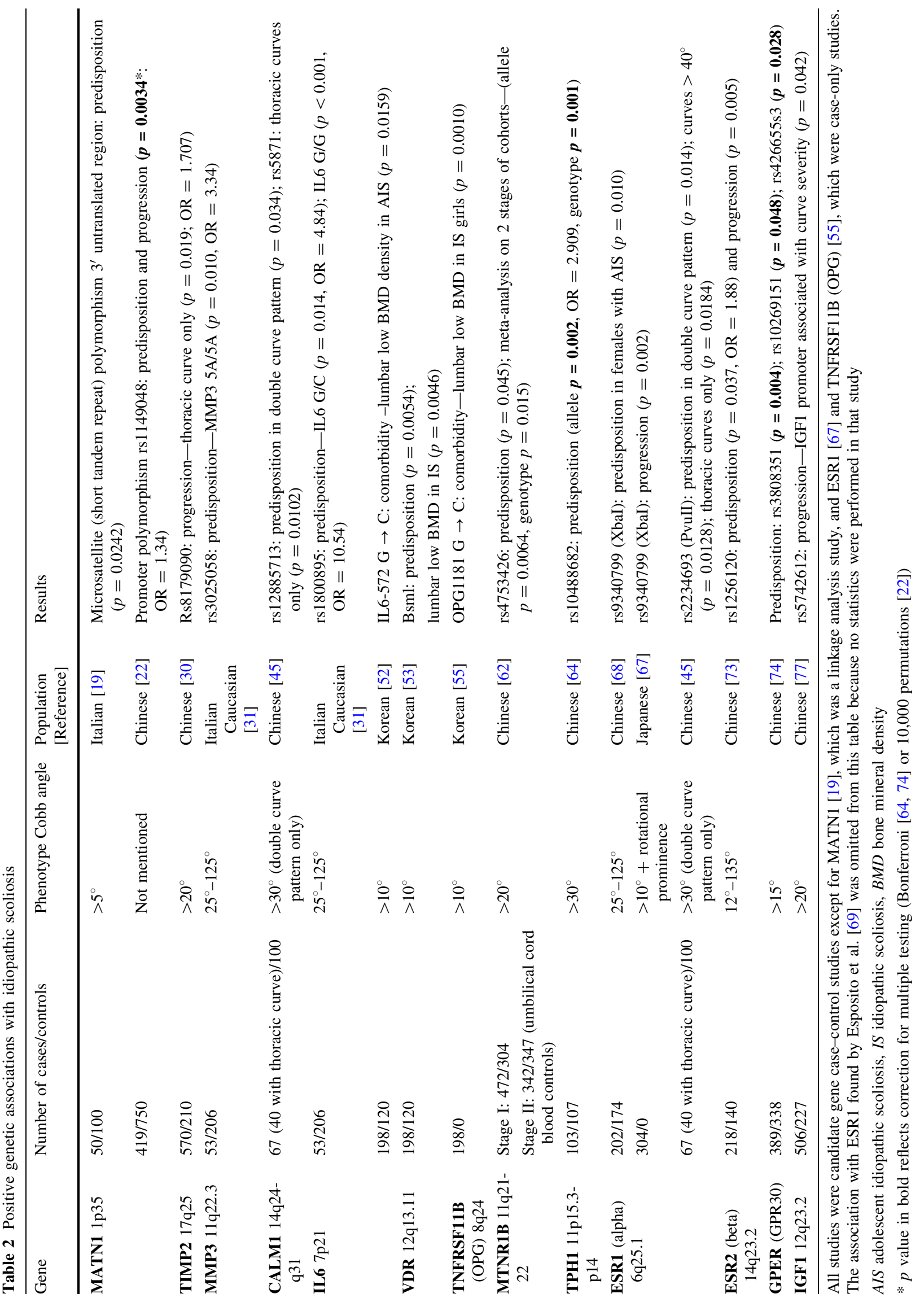




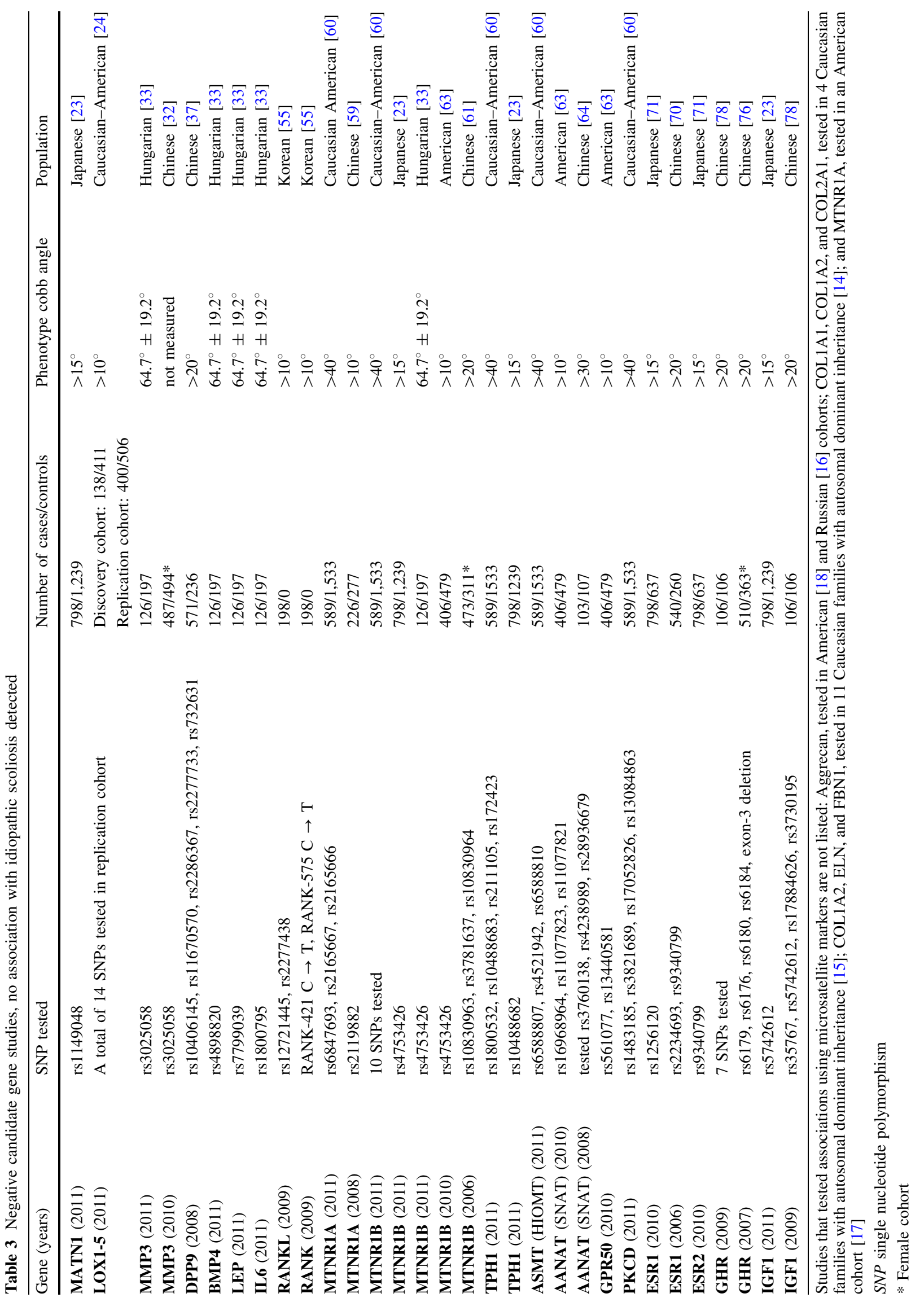


with bone biopsies showing an abnormal histomorphometric profile of bone cell activity [46-51]. However, the precise mechanisms and causes of bone loss in IS have not been identified. To discover genes associated with osteopenia in IS, genes potentially associated with osteoporosis were tested. IL6 was found to be associated with curve predisposition in a small Italian cohort (53 cases/ 206 controls) [31], but this finding was not confirmed in a slightly larger Hungarian sample (126 cases/197 controls) [33]. The same marker was not polymorphic in a larger (487 cases/494 controls) cohort of Chinese females [32]. Although not associated with IS predisposition or severity, a different $I L 6$ variant was found to be associated with low lumbar bone mineral density in Korean females with IS (198 cases/120 controls) [52]. Furthermore, in a case-only study, the vitamin D receptor gene (VDR) interestingly was associated with curve predisposition and low lumbar bone mineral density in a sample of Korean females (198 cases/120 controls) [53], whilst not with curve progression in 304 Japanese females with IS [54]. The genes for receptor activator of nuclear factor- $\kappa \mathrm{B}$ $(R A N K)$, now known as tumor necrosis factor receptor superfamily member 11a NFKB activator (TNFRSF11A), as well as RANK ligand (RANKL) and osteoprotegerin $(O P G)$, now known as tumor necrosis factor receptor superfamily member 11B (TNFRSF11B), were tested for association with IS severity and/or low bone mineral density in a case-only study of 198 Korean females [55]. The authors found that $O P G$ was associated with low

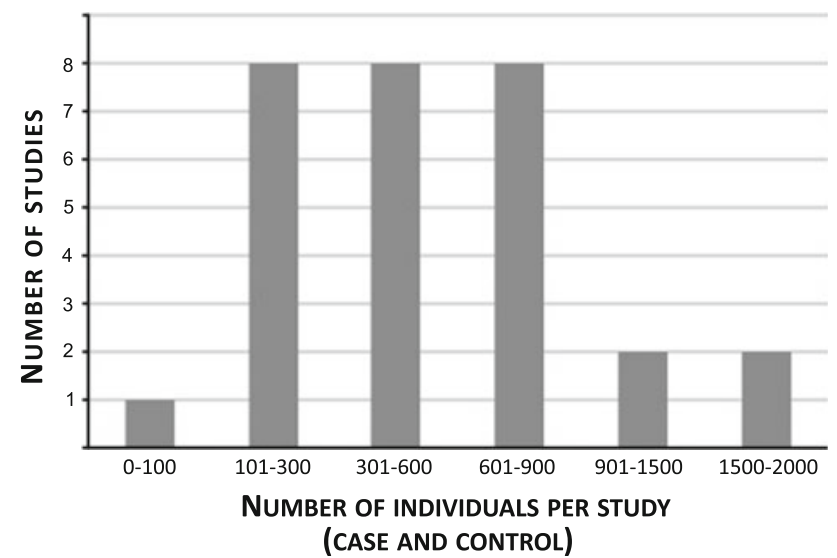

Fig. 2 Total number of individuals per candidate gene study A larger cohort will increase the power of a study to detect associations, particularly if the trait is characterized by genetic heterogeneity. Most candidate gene studies for idiopathic scoliosis fell short of the $1,000+$ individuals required to demonstrate association with a risk allele of low-to-moderate effect

lumbar spine bone mineral density, although $R A N K$ and $R A N K L$ were not associated with IS.

To summarize, CALM1, IL6, LEP, and VDR seemed to be associated with curve predisposition, and IL6,VDR, and $O P G$ with low bone mineral density. These associations need to be verified in larger cohorts. Furthermore, the negative studies described in this section had such small cohorts that we cannot rule out genetic associations for these candidates without further study.

Table 4 Genome-wide parametric linkage results for idiopathic scoliosis

\begin{tabular}{|c|c|c|c|c|c|}
\hline Reference & Pedigree characteristics & Cobb angle & Genetic inheritance & Locus & Statistics \\
\hline \multicolumn{6}{|l|}{ Single-family studies } \\
\hline Salehi et al. [94] & $\begin{array}{l}4 \text { generations, } 11 \text { affected } \\
\text { out of } 17\end{array}$ & $10^{\circ}-20^{\circ}$ & $\mathrm{AD}$, pen $=1$ & $17 \mathrm{p} 11$ & $Z_{\max }=3.20$ \\
\hline Justice et al. [95] & 6 affected & $>10^{\circ}$ & $\begin{array}{l}\text { XLD, } \\
\text { pen } F=0.90 \\
\text { pen } \mathrm{M}=0.79\end{array}$ & $\mathrm{Xq} 22.3-\mathrm{q} 27.2$ & $\mathrm{LOD}=2.23$ \\
\hline Ocaka et al. [29] & $\begin{array}{l}5 \text { generations, } 8 \text { affected } \\
\text { out of } 21\end{array}$ & $15^{\circ}-65^{\circ}$ & $\mathrm{AD}$, pen $=0.80$ & $9 \mathrm{q} 31.2-\mathrm{q} 34.2$ & $Z_{\max }=3.64$ \\
\hline Gurnett et al. [96] & $\begin{array}{l}5 \text { generations, } 9 \text { affected } \\
\text { out of } 22+4 \text { pectus } \\
\text { excavatum }\end{array}$ & $15^{\circ}-70^{\circ}$ & $\mathrm{AD}$, pen $=0.80$ & $18 \mathrm{q} 12.1-\mathrm{q} 12.2$ & $\begin{array}{l}\mathrm{LOD}_{\max } \mathrm{AIS}+\mathrm{PE}=3.86 \\
\mathrm{LOD}_{\max } \mathrm{AIS}=2.77\end{array}$ \\
\hline Edery et al. [98] & $\begin{array}{l}3 \text { generations, } 11 \text { affected } \\
\text { out of } 18\end{array}$ & $15^{\circ}-41^{\circ}$ & $\mathrm{AD}$, pen not noted & $\begin{array}{l}3 q 12.1 \\
5 q 13.3\end{array}$ & $\begin{array}{l}Z_{\max }=3.00 \\
Z_{\max }=3.01\end{array}$ \\
\hline \multicolumn{6}{|l|}{ Multi-family studies } \\
\hline Chan et al. [35] & 7 families, 25 affected & $>10^{\circ}$ & $\mathrm{AD}$, pen $=0.80$ & $19 \mathrm{p} 13.3$ & $\mathrm{LOD}=4.48$ \\
\hline Ocaka et al. [29] & $\begin{array}{l}2 \text { families, } 16 \text { affected out } \\
\text { of } 49\end{array}$ & $11^{\circ}-55^{\circ}$ & $\mathrm{AD}$, pen $=0.80$ & 17q25.3-qtel & LODcomb $=3.78$ \\
\hline Raggio et al. [97] & $\begin{array}{l}7 \text { families, } 18 \text { affected out } \\
\text { of } 50\end{array}$ & $>10^{\circ}$ & $\begin{array}{l}\mathrm{AR}, \alpha=1 \\
\mathrm{AD}, \alpha=1\end{array}$ & $12 \mathrm{p}$ & $\begin{array}{l}\text { HLOD }=3.2 \\
\text { HLOD }=3.7\end{array}$ \\
\hline
\end{tabular}

$A D$ autosomal dominant, $A R$ autosomal recessive, $F$ female, $M$ male, pen penetrance, $X L D$ X-linked dominant 
Fig. 3 Six genome-wide linkage studies derived from a large idiopathic scoliosis cohort. One model-dependent [95] and five model-free studies [36, 99$102]$ are shown, with their major findings. Levels of significance are indicated, based on recommendations by Lander $\mathrm{E}$ and Kruglyak L [92]: (asterisk), suggestive; (double asterisk), significant; (triple asterisk), highly significant. $A D$ autosomal dominant, $X L D$ $\mathrm{X}$-linked dominant, $L O D$ logarithm of odds

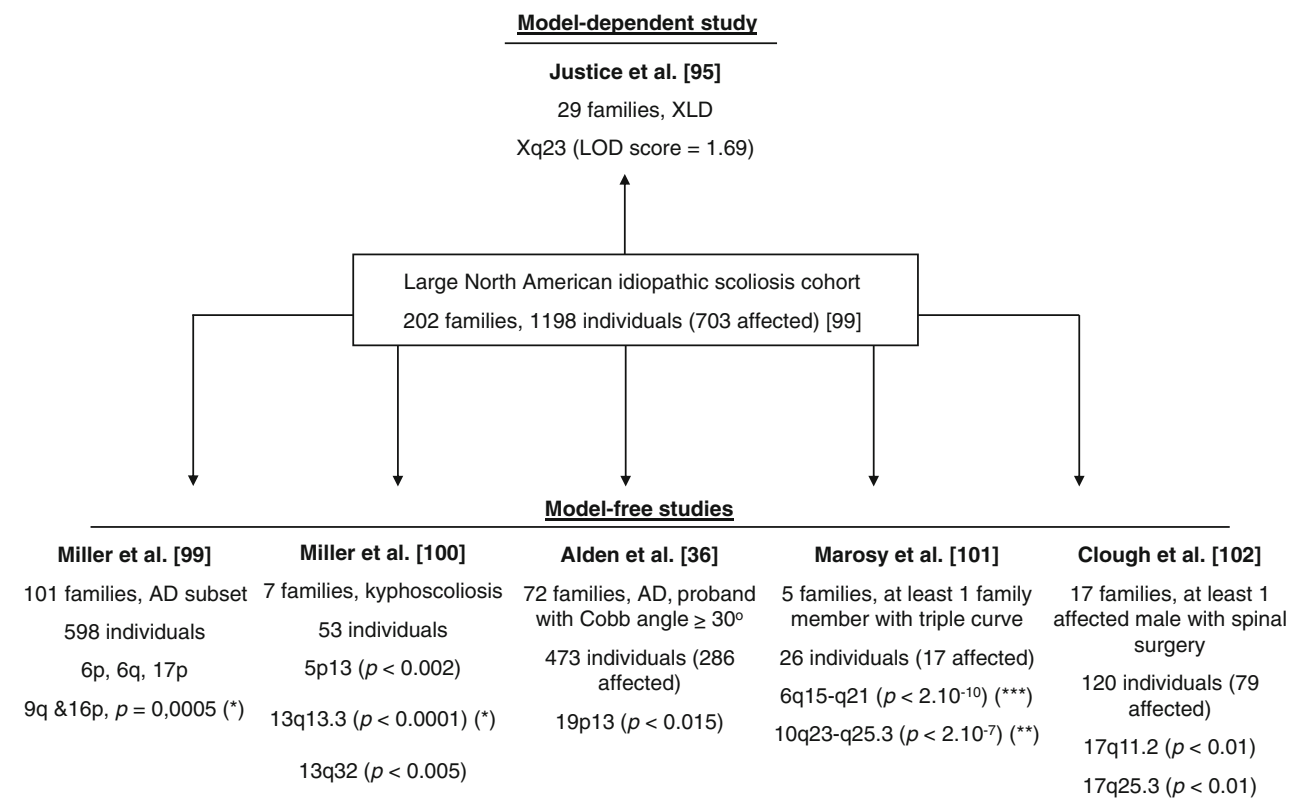

Table 5 Genome-wide nonparametric linkage results for idiopathic scoliosis

\begin{tabular}{|c|c|c|c|c|}
\hline Study & Pedigree characteristics & Cobb angle & Locus & Statistics \\
\hline Chan et al. [35] & 7 families 25 affected & $>20^{\circ}$ & $19 \mathrm{p} 13.3$ & $\mathrm{NPL}=5.36, p=3.10^{-5}(* *)$ \\
\hline Gao et al. [103] & 53 families 130 affected & $15^{\circ}-113^{\circ}$ & $8 \mathrm{q} 12(C D H 7)$ & $\begin{array}{l}\mathrm{Zlr}=2.72, p=2.10^{-4}(*) \\
p_{\text {TDTae }}=2.10^{-4} \\
p_{\text {HHRR }}=0.001\end{array}$ \\
\hline
\end{tabular}

$N P L$ nonparametric linkage, model-independent

Significant $(* *)$ and suggestive $(*)$ results, as per recommendations by Lander E and Kruglyak L [92]

Melatonin signaling pathway

Genes related to melatonin were considered IS candidates because chickens and rats with little or no circulating melatonin developed spinal curvature, preventable by the readministration of melatonin [56, 57]. However, the lack of any significant differences in melatonin levels between IS patients and controls suggested that IS in humans might be caused by other components of the melatonin signaling pathway [58]. Therefore, the genes encoding melatonin receptors 1A (MTNRIA; Mel-1A-R) and 1B (MTNRIB; $M T 2$; $M e l-1 B-R)$ were tested as candidates. Genetic variants of MTNRIA were not associated with IS, in a linkage study of 47 American families with autosomal dominant inheritance [17], nor in a larger Chinese female cohort (226 cases/277 controls) [59] or American cohort (589 cases/ 1,533 controls) [60]. For MTNRIB, Qiu XS et al. [61] found no association between IS and three polymorphisms in the coding region, in Chinese females (473 cases/311 controls). The group later used a 2-phase case-control study (phase I 472 cases/304 controls; phase II 342 cases/ 347 umbilical cord blood samples as controls) to demonstrate an association between promoter polymorphism rs4753426 and curve predisposition, among Chinese females [62]. In an American population, there were no polymorphisms in the coding region of $M T N R 1 B$; hence the negative results from the first Chinese study could not be replicated. The rs4753426 promoter polymorphism was tested but did not replicate the association with curve predisposition (406 cases/479 controls) [63]. Associations with the promoter SNP were further ruled out in an independent American study (589 cases/1,533 controls) [60], in Hungary (126 cases/197 controls) [33], and in Japan (798 cases/1,239 controls) [23].

The gene for tryptophan hydroxylase 1 (TPH1), an enzyme essential for serotonin biosynthesis (a precursor of melatonin), was associated with curve predisposition in a Chinese cohort (103 cases/107 controls) [64], but not in Japanese (798 cases/1,239 controls) [23] or Caucasian American (589 cases/1,533 controls) cohorts [60]. Other components of the melatonin pathway not associated with IS included aralkylamine $N$-acetyltransferase (AANAT), previously known as serotonin $N$-acetyltransferase (SNAT), in a Chinese study (103 cases/107 controls) [64] and in the United States (589 cases/1,533 controls) [60]; G proteincoupled receptor $50(G P R 50)$ in the United States (406 
cases/479 controls) [63]; and acetylserotonin $O$-methyltransferase $(A S M T)$, previously known as hydroxyindole $O$-methyltransferase $(H I O M T)$ and protein kinase $\mathrm{C}$ delta $(P K C D)$ in a separate American cohort (589 cases/1,533 controls) [60]. Although the retinoic acid receptor-related orphan receptor alpha gene (RORA) was tested in the United States along with GPR50, no polymorphisms were found [63].

To summarize, none of the melatonin pathway-associated genes seemed to be associated with IS. Although an association with MTNRIA, MTNR1B, and TPH1 was suggested by smaller studies, larger cohorts did not support their conclusions. These later studies were sufficiently powered to detect any potential effects had they been present.

\section{Puberty and growth}

Because curve pathogenesis in scoliosis coincides with growth and adolescence, genes involved in the somatotrophic and androgenic axes were considered potential IS candidates. The gene encoding cytochrome P450 17 $\alpha$ hydroxylase ( $C Y P 17)$ was considered a likely candidate for IS progression because of its critical roles in androgen synthesis. In a cohort of 304 Japanese females, no association with IS was found [54]. Of note, both forms of the estrogen receptor, ESR1 (also known as ER $\alpha$ ) and ESR2 (also known as $\mathrm{ER} \beta$ ), are present in osteoblasts and osteoclasts [65], indicating that estrogen regulates osteoblast function directly [66]. The ESRl gene has been extensively examined as it contains the polymorphic sites PvuII (rs2234693) and XbaI (rs9340799). XbaI (but not PvuII) was identified as a factor in IS progression in a caseonly study of 304 Japanese females [67]; in Chinese females (202 cases/174 controls), it was associated with curve predisposition, progression, and abnormal growth [68]. In a separate Chinese study, analysis of a small cohort of patients with double-curve patterns only (67 cases/100 controls) suggested that PvuII (but not Xba1) was associated with curvature [45]. Using restriction site analysis, Esposito et al. [69] reported that XbaI was associated with low levels of steroids in several Italian females with IS (4 out of 174 cases/104 controls), although no statistical analyses were effected. However, associations with Xba1 and PvuII were not confirmed in a larger cohort of Chinese females (540 cases/260 controls) [70], nor was the association with Xba1 replicated in a larger Japanese study (798 case/637 control) [71]. Although ESR1 is the major estrogen receptor in bone, it has been shown that in females, the ESR2 gene can modulate the action of ESR1 [72]. In China, the ESR2 polymorphism rs1256120 was associated with curve predisposition and progression (218 case/140 control) [73], though the association was not confirmed in a larger Japanese cohort (798 cases/637 controls) [71]. Recently, the gene for the novel G proteincoupled estrogen receptor GPER (also known as GPR30) was found to be associated with curve severity, but not curve predisposition, in a sample of Han Chinese (389 cases/338 controls) [74].

There is evidence that estrogen enhances the growth hormone/insulin-like growth factor (IGF-1) axis, in both males and females, and is the main mediator of the accelerated linear growth and increases in bone dimensions observed during early-to-mid puberty [75]. Because accelerated linear growth is related to curve progression, genes that define this process are candidates for inclusion in IS research. Although no association was found between IS and the gene for the growth hormone receptor $(G H R)$ in a cohort of Chinese females (510 cases/363 controls) [76], IGF 1 was demonstrably associated with curve severity in a separate cohort of Chinese females (506 cases/227 controls) [77]. Neither gene, however, appeared to be related to IS in a small independent Chinese cohort (106 cases/106 controls) [78]. The lack of association between IS and IGF 1 was further confirmed in a large Japanese cohort (798 cases/1,239 controls) [23].

To summarize, associations in small populations between common polymorphisms of the genes encoding the $\alpha$ - and $\beta$-estrogen receptors and IS were not confirmed in two larger studies. Another two studies found no association for GHR. Whether IGF1 or GPER are associated with IS needs to be confirmed in larger cohorts.

\section{Important considerations for candidate gene studies in IS}

A successful candidate gene is one that demonstrates a truly significant association with a disease. The truth of an association is suggested by the power of the study and proven by replication studies. Generally, the success rate for candidate gene studies has been poor. A 2002 review of 603 published association studies for human disease showed replication of results in only $1 \%$ of the studies [79]. This lack of success is indicative of poor study design in defining the phenotype to be tested, the selection of controls, selection of genetic markers, and adequate sample size [80, 81].

For case-control studies, whether they are candidate gene or genomic association studies, the case population has to be well defined to avoid genetic and environmental heterogeneity that would decrease the power of detection and hinder replication results. This is of particular concern in IS because curve phenotype ostensibly derives from various underlying etiologies. Some studies have attempted to refine the phenotype with clinical parameters, such as 
considering only double curves [45] or pronounced curves (greater than $40^{\circ}$ ) $[16,33,60]$. The recent identification of biochemical endophenotypes for IS [82-84] may thus potentially reduce the heterogeneity confounding current genetic studies. Endophenotypes as conceived by Gottesman and colleagues [85, 86] are heritable, quantitative traits associated with an illness both epidemiologically and conceptually, in the sense of being on the putative path from genes to molecular biological mechanisms. They are state-independent (i.e., present not only during acute illness), co-segregate within families, and may appear in unaffected relatives of individuals with the disorder because they represent vulnerability for the disorder, but are at a higher prevalence in affected individuals as compared with the general population. For complex phenotypes such as IS, an optimal case definition will contain both clinical and biologically relevant information, and this definition will likely change over time as more information becomes available [80].

It is possible that locus or allelic heterogeneity contributes to observed variation in IS. Therefore, detection of an association would require a larger sample size, regardless of disease prevalence [87]. Most candidate gene studies for IS had small cohorts, so it is difficult to discern whether associations were not replicated in other cohorts (same or different ethnic background) as a consequence of genetic heterogeneity or ascertainment bias (e.g., "winner's curse") [88] (Fig. 2). Based on estimations from Hattersley and McCarthy [89], a study needs thousands of individuals to detect a common variant of a risk allele with a low-to-moderate effect. For example, for an allele with a frequency of $20 \%$ in controls, detection of a susceptibility allele at a 0.01 level of significance with $90 \%$ power would require 1,255 individuals (assuming an odds ratio of 1:3). Among the 34 candidate gene studies reviewed here, only three recent association studies had more than 1,000 participants $[23,60,71]$, all three showing negative results. Furthermore, because it is well known that originally reported effect sizes are likely to be biased upward [88, 90, 91], a replication study should calculate its estimated sample size based on the anticipation of an effect smaller in size than the one originally reported.

\section{Genome-wide studies}

We examined 14 genome-wide family-based linkage studies for IS and two GWAS, all published after the year 2000. All defined the phenotype as a lateral curvature of the spine with a minimum Cobb angle of $10^{\circ}$.

Typically, two approaches are used for linkage analysis: parametric and non-parametric. The parametric logarithm of odds (LOD) score method is a model-dependent approach. Mode of inheritance, crossover rate, morbid gene frequency, trait penetrance, phenocopy rate, and allele frequencies have to be provided. Either single-point or multipoint calculations can be made. In single-point analysis, linkage between a trait and a given marker/locus is indicated by an LOD score $\geq 3$ for autosomes (odds ratio 1,000:1), or $\geq 2$ for the $X$ chromosome (odds ratio 100:1). Conversely, a LOD score $\leq-2$ is evidence for exclusion of the locus (odds less than 1:100 that the locus is linked). For multipoint analysis, an LOD score of 3.3 ( $p$ value around $10^{-5}$ ) is considered significant linkage [92]. The second approach to linkage analysis, a non-parametric or modelindependent approach, is based on the hypothesis that relatives sharing the same trait should share heritable alleles. Other than allele frequencies, the other criteria necessary for parametric analysis are not useful. A LOD score of $2\left(p\right.$ value of $\left.7 \times 10^{-4}\right)$ is suggestive of linkage, a LOD score of 3.3 ( $p$ value of $2 \times 10^{-5}$ ) is considered significant linkage, and a LOD score of 5.4 ( $p$ value of $3 \times 10^{-7}$ ) is considered highly significant linkage. Importantly, significant observations should be reproducible in an independent cohort, with $p<0.01$, according to Lander and Kruglyak [92].

\section{Parametric linkage analysis}

With linkage studies, the number of meioses is more pertinent than the number of families, as different susceptibility genes may segregate among different families [93]. For this reason, a study with one or several large families containing many affected members is optimal for detection of susceptibility loci. In the present review, seven studies using informative families identified nine loci linked to IS (Table 4) [29, 35, 94-98]. In four of these studies, single multiplex informative families displayed autosomal dominant inheritance reaching significance, according to the LOD threshold required for valid linkage [29, 94, 96, 98]. A fifth one showed X-linked dominant transmission among 29 families (202 individuals identified, overall LOD score $=1.69$, of which a single family contributed a LOD score $=2.23$ ) (Fig. 3; Table 4) [95]. With regards to locus $18 \mathrm{q} 12.1-12.2$, it is important to note that the LOD score was below 3 when individuals with pectus excavatum were removed from the analysis $\left(\mathrm{LOD}_{\max } \mathrm{AIS}=2.77\right)$ [96], suggesting that in this family, both phenotypes were linked to the same locus but that the loss of power was likely due to reduced sample size.

In addition to the six primary regions noted above, three secondary loci were identified using cohorts of multiple smaller families [29, 35, 97]. For the most part, these families included less than 6 affected individuals each, except for family SC36, which had 10 affected individuals out of 25 [29]. The combined LOD score reported 
corresponded to the sum of genetic contributions from each family, as none of the pedigrees reached statistical significance independently. According to the published data, family SC36 was the most genetically informative, as it showed a LOD score of 2.64 at $17 q 25.3$ [29].

To summarize, nine loci were identified as linked to IS. Of these, seven met the threshold for significance: $3 q 12.1$, 5q13.3, 9q31.2-34.2, 12p, 17p11, 19p13.3, and Xq22.327.2 .

\section{Non-parametric linkage analysis}

Six of the genome-wide linkage studies were subsets of a larger North American cohort of 202 families (1,198 individuals, including 703 individuals with IS). Five of these studies were model-independent [36, 99-102], while one was a parametric study described in the previous section [95] (Fig. 3). Various traits were analyzed (kyphoscoliosis, scoliosis, gender-related severe scoliosis, curve pattern), illustrating the difficulty in defining the IS phenotype. Regions on chromosomes $6 \mathrm{p}, 6 \mathrm{q}, 9 \mathrm{q}, 16 \mathrm{p}$, and $17 \mathrm{p}$ were found to be linked to curve susceptibility in 101 families with autosomal dominant inheritance [99]. Three other loci $(5 \mathrm{p} 13,13 \mathrm{q} 13.3$ and 13q32) were linked to kyphoscoliosis (defined by a sagittal curve $>40^{\circ}$ ) in a subgroup of seven families [100]. One locus (19p13) was linked to curve progression in families whose probands had a Cobb angle $\geq 30^{\circ}$ [36]. Two loci were linked to triple curve scoliosis (6q15-q21 and 10q23-q25.3) [101], and a chromosomal region $(17 q)$ to male-specific severe scoliosis [102]. Not all these regions were deemed significant by Lander and Kruglyak standards, however [92] (Fig. 3).

Using different cohorts, Chan et al. [35] identified the 19p13.3 locus as linked to IS in Chinese families and Gao et al. [103] suggested linkage between the gene for the calcium-dependent adhesion transmembrane protein cadherin 7 type 2 ( $C D H 7)(8 q 12)$ and IS in American individuals of European descent (Table 5).

Thus, of the seven model-independent studies [35, 36, 99-103], only three loci reached statistical significance: 6q15-q21, 10q23-q25.3 and 19p13.3.

Important candidate regions in genome-wide linkage studies

Taken together, the parametric and nonparametric genomewide linkage studies revealed various regions of interest to IS. In 2005, Miller et al. [99] first identified 9q31-q34 with suggestive linkage $(p<0.006)$, a finding supported in 2007 by Ocaka et al. [29] in a single family $\left(Z_{\max }=3.64\right)$. According to Lander and Kruglyak [92], a $p$ value of 0.01 signifies confirmation of linkage in a replication cohort. Also, although not the strongest locus according to the standards discussed here, the region at $17 \mathrm{q} 25$ was noteworthy. First identified by Ocaka et al. [29] in 2007 using two families $\left(Z_{\max }=2.64\right.$ and $\left.Z_{\max }=1.81\right)$, this region was also identified by Clough et al. [102] in 2010 $(p<0.01)$. Of the 19 families described, 18 had at least one individual with spinal surgery or bracing, suggesting that this locus was linked to curve severity.

Genome-wide association studies

Two GWAS on IS were recently published [104, 105]. One consisted of a discovery cohort of 419 families (total of 1,122 individuals) and three replication cohorts, in which 327,000 SNPs were genotyped [104]. While statistical thresholds were not clearly mentioned, transmission disequilibrium testing on the discovery cohort followed by case-control comparisons on the replication cohorts identified SNPs located on chromosome 3 in the region of the L1 cell adhesion molecule gene $(C H L 1) / L O C 642891$ [rs10510181 OR = $\left.1.37, \mathrm{CI}=(1.20-1.58), p=8.22 .10^{-7}\right]$. Furthermore, the authors reported the replicated association of the Down syndrome cell adhesion molecule gene (DSCAM) [combined results for $\mathrm{rs} 2222973 \mathrm{OR}=0.59, \mathrm{CI}=(0.48-0.74), p=$ $1.46 \cdot 10^{-6}$ ]. Dscam partial knockdowns had previously been shown to produce crooked tails in zebrafish embryos [106]. These two genes are involved in axon guidance pathways, evidence of a potential neuropathology underlying IS. Modest associations were found in clusters within the 9q31q34 locus, but the authors failed to replicate previous observations concerning linkage/association of $\mathrm{CDH7}$.

The second study consisted of a discovery cohort composed of 1,050 Japanese cases and 1,474 Japanese controls and a replication cohort of 326 affected adolescents, and 9,823 controls, for which, here again, 327,000 SNPs were genotyped [105]. Three SNPs (rs11190870, rs625039 and rs11598564) reached genome-wide significance ( $p$ value of $1 \times 10^{-7}$ ) and were located near the ladybird homeobox 1 (LBX1) gene locus (10q24.32). Even hypothesizing an abnormal somatosensory etiology for IS in which $L B X 1$ could be involved, the role of this gene has to be further explored. As none of the previous GWAS results were found, ethnic and/or genetic heterogeneity may be assumed.

\section{Conclusions}

In this comprehensive review of the genetics underlying IS, we analyzed 50 studies. Findings involved genes related to connective tissue structure, bone formation/metabolism, melatonin signaling pathways, puberty and growth, and axon guidance pathways. The genetic basis for the etiology and prognosis of IS remains elusive, however. As with 
other genetic studies, the goals were to identify susceptibility genes for IS, define disease modifying genes, and explain why some curves progress to severity while others do not (genes that could be shared with the asymptomatic healthy population). The major difficulty faced by IS genetic studies is phenotypic and genetic heterogeneity. We found that IS genetic studies were overrepresented by underpowered studies that suggested an association, and then by underpowered replication studies that could not confirm or refute the original hypotheses. Although an increase in the number of individuals generally enhances the power of a study to detect an effect, genetic heterogeneity in complex diseases like IS is a major obstacle that cannot be overcome by such means alone.

With the advent of high-throughput technologies, future studies will be able to genotype a greater number of markers to possibly identify causal variants. However, understanding the difficulties surrounding this complex phenotype and the strengths and weaknesses of prior studies is crucial for progress in defining the genetics of this deformity. The use of biological endophenotypes such as those defined by Moreau et al. as well as restricted clinical definitions may facilitate the partitioning of variation and increase the power of detecting genetic associations. In addition, replication studies should use power analysis to minimize the possibility of false negatives. Further, when multiple polymorphisms are tested, an appropriate correction for significance thresholds needs to be applied.

Acknowledgments We are grateful to Dr. Constantin Polychronakos (McGill University) for his critical review and suggestions. The authors wish to thank Danielle Buch, medical writer/editor at the Applied Clinical Research Unit of the CHU Sainte-Justine Research Center, for critical revision and substantive editing of the manuscript. This work was supported in part by a research grant from Génome Québec to Dr. Moreau. Dr. Kristen F. Gorman is the recipient of a CHU Sainte-Justine Foundation Postdoctoral Scholarship for Excellence.

\section{Conflict of interest None.}

Open Access This article is distributed under the terms of the Creative Commons Attribution License which permits any use, distribution, and reproduction in any medium, provided the original author(s) and the source are credited.

\section{References}

1. Miller NH (2007) Genetics of familial idiopathic scoliosis. Clin Orthop Relat Res 462:6-10

2. Grauers A, Rahman I, Gerdhem P (2011) Heritability of scoliosis. Eur Spine J. doi:10.1007/s00586-011-2074-1

3. Axenovich TI, Zaidman AM, Zorkoltseva IV, Tregubova IL, Borodin PM (1999) Segregation analysis of idiopathic scoliosis, demonstration of a major gene effect. Am J Med Genetics 86:389-394
4. Cowell HR, Hall JN, MacEwen GD (1972) Genetic aspects of idiopathic scoliosis, a Nicholas Andry Award Essay. Clin Orthop 86:121-131

5. Riseborough EJ, Wynne-Davies RA (1973) A genetic survey of idiopathic scoliosis in Boston, Massachusetts. J Bone Joint Surg Am 55(5):974-982

6. Horton D (2002) In: Rimoin DL, Connor JM, Pyeritz RE, Korf BR (eds) Emery and Rimoin's principles and practices of medical genetics, 5th edn. Churchill Livingstone Elsevier, Amsterdam, pp 4236-4244

7. Andersen MO, Thomsen K, Kyvik KO (2007) Adolescent idiopathic scoliosis in twins: a population-based survey. Spine (Phila Pa 1976) 32(8):927-930

8. Hermus JP, van Rhijn LW, van Ooij A (2007) Non-genetic expression of adolescent idiopathic scoliosis: a case report and review of the literature. Eur Spine J 16(Suppl 3):338-341

9. Weiss HR (2007) Idiopathic Scoliosis: how much of a genetic disorder? Report of five pairs of monozygotic twins. Dev Neurorehabil 10(1):67-73

10. Fazal MA, Edgar M (2006) Detection of adolescent idiopathic scoliosis. Acta Orthop Belg 72:184-186

11. Wacholder S, Chanock S, Garcia-Closas M, El Ghormli L, Rothman N (2004) Assessing the probability that a positive report is false: an approach for molecular epidemiology studies. J Natl Cancer Inst 96(6):434-442

12. Hirschhorn JN, Lohmueller K, Byrne E, Hirschhorn K (2002) A comprehensive review of genetic association studies. Genet Med $4(2): 45-61$

13. Yu W, Gwinn M, Clyne M, Yesupriya A, Khoury MJ (2008) A navigator for human genome epidemiology. Nat Genet 40(2): 124-125

14. Carr AJ, Ogilvie DJ, Wordsworth BP, Priestly LM, Smith R, Sykes B (1992) Segregation of structural collagen genes in adolescent idiopathic scoliosis. Clin Orthop Relat Res 274: 305-310

15. Miller NH, Mims B, Child A, Milewicz DM, Sponseller P, Blanton SH (1996) Genetic analysis of structural elastic fiber and collagen genes in familial adolescent idiopathic scoliosis. J Orthop Res 14(6):994-999

16. Zorkol'tseva IV, Liubinskiǐ OA, Sharipov RN, Zaǐdman AM, Aksenovich TI, Dymshits GM (2002) Analysis of polymorphism of the number of tandem repeats in the aggrecan gene exon G3 in the families with idiopathic scoliosis. Russ J Genet 38(2):196-200

17. Morcuende JA, Minhas R, Dolan L, Stevens J, Beck J, Wang K, Weinstein SL, Sheffield V (2003) Allelic variants of human melatonin 1A receptor in patients with familial adolescent idiopathic scoliosis. Spine (Phila Pa 1976) 28(17):2025-2028

18. Marosy B, Justice CM, Nzegwu N, Kumar G, Wilson AF, Miller $\mathrm{NH}$ (2006) Lack of association between the aggrecan gene and familial idiopathic scoliosis. Spine (Phila Pa 1976) 31(13): $1420-1425$

19. Montanaro L, Parisini P, Greggi T, Di Silvestre M, Campoccia D, Rizzi S, Arciola CR (2006) Evidence of a linkage between matrilin-1 gene (MATN1) and idiopathic scoliosis. Scoliosis 1:21

20. Chen Q, Zhang Y, Johnson DM, Goetinck PF (1999) Assembly of a novel cartilage matrix protein filamentous network: molecular basis of differential requirement of von Willebrand factor A domains. Mol Biol Cell 10:2149-2162

21. The International HapMap Consortium (2003) The International HapMap Project Nature 426: 789-796

22. Chen Z, Tang NL, Cao X, Qiao D, Yi L, Cheng JC, Qiu Y (2009) Promoter polymorphism of matrilin-1 gene predisposes to adolescent idiopathic scoliosis in a Chinese population. Eur J Hum Genet 17(4):525-532

23. Takahashi Y, Matsumoto M, Karasugi T, Watanabe K, Chiba K, Kawakami N, Tsuji T, Uno K, Suzuki T, Ito M, Sudo H, Minami S, 
Kotani T, Kono K, Yanagida H, Taneichi H, Takahashi A, Toyama Y, Ikegawa S (2011) Lack of association between adolescent idiopathic scoliosis and previously reported single nucleotide polymorphisms in MATN1, MTNR1B, TPH1, and IGF1 in a Japanese population. J Orthop Res 29(7):1055-1058

24. McGregor TL, Gurnett CA, Dobbs MB, Wise CA, Morcuende JA, Morgan TM, Menon R, Muglia LJ (2011) Common polymorphisms in human lysyl oxidase genes are not associated with the adolescent idiopathic scoliosis phenotype. BMC Med Genet 12:92

25. Varghese S (2006) Matrix metalloproteinases and their inhibitors in bone: an overview of regulation and functions. Front Biosci 11:2949-2966

26. Ortega N, Behonick DJ, Werb Z (2004) Matrix remodeling during endochondral ossification. Trends Cell Biol 14:86-93

27. Brew K, Dinakarpandian D, Nagase H (2000) Tissue inhibitors of metalloproteinases: evolution, structure and function. Biochim Biophys Acta 1477:267-283

28. Gomez DE, Alonso DF, Yoshiji H, Thorgeirsson UP (1997) Tissue inhibitors of metalloproteinases: structure, regulation and biological functions. Eur J Cell Biol 74:111-122

29. Ocaka L, Zhao C, Reed JA, Ebenezer ND, Brice G, Morley T, Mehta M, O'Dowd J, Weber JL, Hardcastle AJ, Child AH (2008) Assignment of two loci for autosomal dominant adolescent idiopathic scoliosis to chromosomes 9q31.2-q34.2 and 17q25.3-qtel. J Med Genet 45:87-92

30. Jiang J, Qian B, Mao S, Zhao Q, Qiu X, Liu Z, Qiu Y (2011) A Promoter Polymorphism of Tissue Inhibitor of Metalloproteinase-2 (TIMP-2) Gene Is Associated With Severity of Thoracic Adolescent Idiopathic Scoliosis. Spine (Phila Pa 1976) Jan 11: doi:10.1097/BRS.0b013e31820e71e3

31. Aulisa L, Papaleo P, Pola E, Angelini F, Aulisa AG, Tamburrelli FC, Pola P, Logroscino CA (2007) Association between IL-6 and MMP-3 gene polymorphisms and adolescent idiopathic scoliosis: a case-control study. Spine (Phila Pa 1976) 32(24):2700-2702

32. Liu Z, Tang NL, Cao XB, Liu WJ, Qiu XS, Cheng JC, Qiu Y (2010) Lack of association between the promoter polymorphisms of MMP-3 and IL-6 genes and adolescent idiopathic scoliosis: a case-control study in a Chinese Han population. Spine (Phila Pa 1976) 35(18):1701-1705

33. Mórocz M, Czibula A, Grózer ZB, Szécsényi A, Almos PZ, Raskó I, Illés T (2011) Association study of BMP4, IL6, Leptin, MMP3, and MTNR1B gene promoter polymorphisms and adolescent idiopathic scoliosis. Spine (Phila Pa 1976) 36(2):E123-E130

34. Yu DM, Wang XM, McCaughan GW, Gorrell MD (2006) Extraenzymatic functions of the dipeptidyl peptidase IV-related proteins DP8 and DP9 in cell adhesion, migration and apoptosis. FEBS J 273(11):2447-2460

35. Chan V, Fong GC, Luk KD, Yip B, Lee MK, Wong MS, Lu DD, Chan TK (2002) A genetic locus for adolescent idiopathic scoliosis linked to chromosome 19p13.3. Am J Hum Genet 71(12):401-406

36. Alden KJ, Marosy B, Nzegwu N, Justice CM, Wilson AF, Miller $\mathrm{NH}$ (2006) Idiopathic scoliosis: identification of candidate regions on chromosome 19p13. Spine (Phila Pa 1976) 31(16):1815-1819

37. Qiu XS, Tang NL, Yeung HY, Qiu Y, Cheng JC (2008) Association study between adolescent idiopathic scoliosis and the DPP9 gene which is located in the candidate region identified by linkage analysis. Postgrad Med J 84(995):498-501

38. Canalis E, Economides AN, Gazzerro E (2003) Bone morphogenetic proteins, their antagonists, and the skeleton. Endocr Rev 24:218-235

39. Van den Wijngaard A, Pijpers MA, Joosten PH, Roelofs JM, Van zoelen EJ, Olijve W (1999) Functional characterization of two promoters in the human bone morphogenetic protein- 4 gene. J Bone Miner Res 14:1432-1441
40. van den Wijngaard A, Mulder WR, Dijkema R, Boersma CJ, Mosselman S, van Zoelen EJ, Olijve W (2000) Antiestrogens specifically up-regulate bone morphogenetic protein-4 promoter activity in human osteoblastic cells. Mol Endocrinol 14:623-633

41. Williams JP, Micoli K, McDonald JM, Ann NY (2010) Calmodulin-an often-ignored signal in osteoclasts. Acad Sci 1192:358-364

42. Kindsfater K, Lowe T, Lawellin D, Weinstein D, Akmakjian J (1994) Levels of platelet calmodulin for the prediction of progression and severity of adolescent idiopathic scoliosis. J Bone Joint Surg Am 76(8):1186-1192

43. Lowe TG, Edgar M, Margulies JY, Miller NH, Raso VJ, Reinker KA, Rivard CH (2000) Etiology of idiopathic scoliosis: current trends in research. J Bone Joint Surg Am 82-A(8): 1157-1168

44. Lowe TG, Burwell RG, Dangerfield PH (2004) Platelet calmodulin levels in adolescent idiopathic scoliosis (AIS): can they predict curve progression and severity? Summary of an electronic focus group debate of the IBSE. Eur Spine J 13(3): 257-265

45. Zhao D, Qiu GX, Wang YP, Zhang JG, Shen JX, Wu ZH (2009) Association between adolescent idiopathic scoliosis with double curve and polymorphisms of calmodulin1 gene/estrogen receptor- $\alpha$ gene. Orthop Surg 1(3):222-230

46. Burner WL 3rd, Badger VM, Sherman FC (1982) Osteoporosis and acquired back deformities. J Pediatr Orthop 2:383-385

47. Singh M, Magrath AR, Maini PS (1970) Changes in trabecular pattern of the upper end of the femur as an index of osteoporosis. J Bone Joint Surg [Am] 52-A: 457-467

48. Cook SD, Harding AF, Morgan EL, Nicholson RJ, Thomas KA, Whitecloud TS, Ratner ES (1987) Trabecular bone mineral density in idiopathic scoliosis. J Pediatr Orthop 7:168-174

49. Suh KT, Lee SS, Hwang SH, Kim SJ, Lee JS (207) Elevated soluble receptor activator of nuclear factor-kappaB ligand and reduced bone mineral density in patients with adolescent idiopathic scoliosis. Eur Spine J 16:1563-1569

50. Thomas KA, Cook SD, Skalley TC, Renshaw SV, Makuch RS, Gross M, Whitecloud TS 3rd, Bennett JT (1992) Lumbar spine and femoral neck bone mineral density in idiopathic scoliosis: a follow-up study. J Pediatr Orthop 12:235-240

51. Cheng JC, Tang SP, Guo X, Chan CW, Qin L (2001) Osteopenia in adolescent idiopathic scoliosis: a histomorphometric study. Spine (Phila Pa 1976) 26:E19-E23

52. Lee JS, Suh KT, Eun IS (2010) Polymorphism in interleukin-6 gene is associated with bone mineral density in patients with adolescent idiopathic scoliosis. J Bone Joint Surg Br 92(8): $1118-1122$

53. Suh KT, Eun IS, Lee JS (2010) Polymorphism in vitamin D receptor is associated with bone mineral density in patients with adolescent idiopathic scoliosis. Eur Spine J 19(9):1545-1550

54. Inoue M, Minami S, Nakata Y, Takaso M, Otsuka Y, Kitahara H, Isobe K, Kotani T, Maruta T, Moriya H (2002) Prediction of curve progression in idiopathic scoliosis from gene polymorphic analysis. Stud Health Technol Inform 91:90-96

55. Eun IS, Park WW, Suh KT, Kim JI, Lee JS (2009) Association between osteoprotegerin gene polymorphism and bone mineral density in patients with adolescent idiopathic scoliosis. Eur Spine J 18(12):1936-1940

56. Machida M, Dubousset J, Imamura Y, Iwaya T, Yamada T, Kimura J (1995) Role of melatonin deficiency in the development of scoliosis in pinealectomized chickens. J Bone Joint Surg Br 77:134-138

57. Machida M, Dubousset J, Imamura $Y$, Iwaya $T$, Yamada $T$, Kimura J, Toriyama S (1994) Pathogenesis of idiopathic scoliosis: sEPs in chicken with experimentally induced scoliosis and in patients with idiopathic scoliosis. J Pediatr Orthop 14: 329-335 
58. Girardo M, Bettini N, Dema E, Cervellati S (2011) The role of melatonin in the pathogenesis of adolescent idiopathic scoliosis (AIS). Eur Spine J 20(1):S68-S74

59. Qiu XS, Tang NL, Yeung HY, Cheng JC, Qiu Y (2008) Lack of association between the promoter polymorphism of the MTNR1A gene and adolescent idiopathic scoliosis. Spine (Phila Pa 1976) 33(20):2204-2207

60. Nelson LM, Ward K, Ogilvie JW (2011) Genetic variants in melatonin synthesis and signaling pathway are not associated with adolescent idiopathic scoliosis. Spine (Phila Pa 1976) 36(1):37-40

61. Qiu XS, Tang NL, Yeung HY, Qiu Y, Qin L, Lee KM, Cheng JC (2006) The role of melatonin receptor 1B gene (MTNR1B) in adolescent idiopathic scoliosis-a genetic association study. Stud Health Technol Inform 123:3-8

62. Qiu XS, Tang NL, Yeung HY, Lee KM, Hung VW, Ng BK, Ma SL, Kwok RH, Qin L, Qiu Y, Cheng JC (2007) Melatonin receptor 1B (MTNR1B) gene polymorphism is associated with the occurrence of adolescent idiopathic scoliosis. Spine (Phila Pa 1976) 32(16):1748-1753

63. Shyy W, Wang K, Gurnett CA, Dobbs MB, Miller NH, Wise C, Sheffield VC, Morcuende JA (2010) Evaluation of GPR50, hMel-1B, and ROR-alpha melatonin-related receptors and the etiology of adolescent idiopathic scoliosis. J Pediatr Orthop 30(6):539-543

64. Wang H, Wu Z, Zhuang Q, Fei Q, Zhang J, Liu Y, Wang Y, Ding Y, Qiu G (2008) Association study of tryptophan hydroxylase 1 and arylalkylamine $N$-acetyltransferase polymorphisms with adolescent idiopathic scoliosis in Han Chinese. Spine (Phila Pa 1976) 33(20):2199-2203

65. Compston JE (2001) Sex steroids and bone. Physiol Rev 81:419-447

66. Lambertini E, Penolazzi L, Giordano S, Del Senno L, Piva R (2003) Expression of the human oestrogen receptor" gene is regulated by promoter F in MG-63 osteoblastic cells. Biochem $\mathrm{J}$ 372:831-839

67. Inoue M, Minami S, Nakata Y, Kitahara H, Otsuka Y, Isobe K, Takaso M, Tokunaga M, Nishikawa S, Maruta T, Moriya H (2002) Association between estrogen receptor gene polymorphisms and curve severity of idiopathic scoliosis. Spine (Phila Pa 1976) 27(21):2357-2362

68. Wu J, Qiu Y, Zhang L, Sun Q, Qiu X, He Y (2006) Association of estrogen receptor gene polymorphisms with susceptibility to adolescent idiopathic scoliosis. Spine (Phila Pa 1976) 31(10): 1131-1136

69. Esposito T, Uccello R, Caliendo R, Di Martino GF, Gironi Carnevale UA, Cuomo S, Ronca D, Varriale B (2009) Estrogen receptor polymorphism, estrogen content and idiopathic scoliosis in human: a possible genetic linkage. J Steroid Biochem Mol Biol 116(1-2):56-60

70. Tang NL, Yeung HY, Lee KM, Hung VW, Cheung CS, Ng BK, Kwok R, Guo X, Qin L, Cheng JC (2006) A relook into the association of the estrogen receptor [alpha] gene (PvuII, XbaI) and adolescent idiopathic scoliosis: a study of 540 Chinese cases. Spine (Phila Pa 1976) 31(21):2463-2468

71. Takahashi Y, Matsumoto M, Karasugi T, Watanabe K, Chiba K, Kawakami N, Tsuji T, Uno K, Suzuki T, Ito M, Sudo H, Minami S, Kotani T, Kono K, Yanagida H, Taneichi H, Takahashi A, Toyama Y, Ikegawa S (2010) Replication study of the association between adolescent idiopathic scoliosis and two estrogen receptor genes. J Orthop Res 29(6):834-837

72. Sims NA, Clément-Lacroix P, Minet D, Fraslon-Vanhulle C, Gaillard-Kelly M, Resche-Rigon M, Baron R (2003) A functional androgen receptor is not sufficient to allow estradiol to protect bone after gonadectomy in estradiol receptor-deficient mice. J Clin Invest 111:1319-1327
73. Zhang HQ, Lu SJ, Tang MX, Chen LQ, Liu SH, Guo CF, Wang XY, Chen J, Xie L (2009) Association of estrogen receptor beta gene polymorphisms with susceptibility to adolescent idiopathic scoliosis. Spine (Phila Pa 1976) 34(8):760-764

74. Peng Y, Liang G, Pei Y, Ye W, Liang A, Su P (2011) Genomic polymorphisms of G-Protein Estrogen Receptor 1 are associated with severity of adolescent idiopathic scoliosis. Int Orthop. doi: 10.1007/s00264-011-1374-8

75. Rubin K (2000) Pubertal development and bone. Curr Opin Endocrinol Diabetes Obes 7:65-70

76. Qiu XS, Tang NL, Yeung HY, Qiu Y, Cheng JC (2007) Genetic association study of growth hormone receptor and idiopathic scoliosis. Clin Orthop Relat Res 462:53-58

77. Yeung HY, Tang NL, Lee KM, Ng BK, Hung VW, Kwok R, Guo X, Qin L, Cheng JC (2006) Genetic association study of insulin-like growth factor-I (IGF-I) gene with curve severity and osteopenia in adolescent idiopathic scoliosis. Stud Health Technol Inform 123:18-24

78. Yang Y, Wu Z, Zhao T, Wang H, Zhao D, Zhang J, Wang Y, Ding Y, Qiu G (2009) Adolescent idiopathic scoliosis and the single-nucleotide polymorphism of the growth hormone receptor and IGF-1 genes. Orthopedics 32(6):411

79. Hirschhorn JN, Lohmueller K, Byrne E, Hirschhorn K (2002) A comprehensive review of genetic association studies. Genet Med 4:45-61

80. Zondervan KT, Cardon LR (2007) Designing candidate gene and genome-wide case-control association studies. Nat Protoc 2(10):2492-2501

81. Cui Y, Li G, Li S, Wu R (2010) Designs for linkage analysis and association studies of complex diseases. Methods Mol Biol 620:219-242

82. Moreau A, Wang DS, Forget S, Azeddine B, Angeloni D, Fraschini F, Labelle H, Poitras B, Rivard CH, Grimard G (2004) Melatonin signaling dysfunction in adolescent idiopathic scoliosis. Spine (Phila Pa 1976) 29(16):1772-1781

83. Azeddine B, Letellier K, Wang DS, Moldovan F, Moreau A (2007) Molecular determinants of melatonin signalling dysfunction in adolescent idiopathic scoliosis. Clin Orthop Relat Res 462:45-52

84. Akoume MY, Azeddine B, Turgeon I, Franco A, Labelle H, Poitras B, Rivard CH, Grimard G, Ouellet J, Parent S, Moreau A (2010) Cell-based screening test for idiopathic scoliosis using cellular dielectric spectroscopy. Spine (Phila Pa 1976) 35(13):E601-E608

85. Gottesman II, Gould TD (2003) The endophenotype concept in psychiatry: etymology and strategic intentions. Am J Psychiatry 160:636-645

86. Chan RC, Gottesman II (2008) Neurological soft signs as candidate endophenotypes for schizophrenia: a shooting star or a Northern star? Neurosci Biobehav Rev 32:957-971

87. Chen C, Yang G, Buyske S, Matise T, Finch SJ, Gordon D (2009) Transmission disequilibrium test power and sample size in the presence of locus heterogeneity. Stat Appl Genet Mol Biol 8(1): Article 44

88. Xiao R, Boehnke M (2009) Quantifying and correcting for the winner's curse in genetic association studies. Genet Epidemiol 33(5):453-462

89. Hattersley AT, McCarthy MI (2005) What makes a good genetic association study? Lancet 366(9493):1315-1323

90. Beavis WD (1994) The power and deceit of QTL experiments: lessons from comparitive QTL studies. In: Proceedings of the Forty-Ninth Annual Corn \& Sorghum Industry Research Conference. American Trade Association, Washington, DC, pp 250-266

91. Garner C (2007) Upward bias in odds ratio estimates from genome-wide association studies. Genet Epidemiol 31:288-295 
92. Lander E, Kruglyak L (1995) Genetic dissection of complex traits: guidelines for interpreting and reporting linkage results. Nat Genet 11(3):241-247

93. Bickeböller H (2000) Investigation of linkage and association: issues on study design. Int Stat Rev 68(1):75-81

94. Salehi LB, Mangino M, De Serio S, De Cicco D, Capon F, Semprini S, Pizzuti A, Novelli G, Dallapiccola B (2002) Assignment of a locus for autosomal dominant idiopathic scoliosis (IS) to human chromosome 17p11. Hum Genet 111(4-5): 401-404

95. Justice CM, Miller NH, Marosy B, Zhang J, Wilson AF (2003) Familial idiopathic scoliosis: evidence of an X-linked susceptibility locus. Spine (Phila Pa 1976) 28(6):589-594

96. Gurnett CA, Alaee F, Bowcock A, Kruse L, Lenke LG, Bridwell KH, Kuklo T, Luhmann SJ, Dobbs MB (2009) Genetic linkage localizes an adolescent idiopathic scoliosis and pectus excavatum gene to chromosome 18 q. Spine (Phila Pa 1976) 34(2): E94-E100

97. Raggio CL, Giampietro PF, Dobrin S, Zhao C, Dorshorst D, Ghebranious N, Weber JL, Blank RD (2009) A novel locus for adolescent idiopathic scoliosis on chromosome 12p. J Orthop Res 27(10):1366-1372

98. Edery P, Margaritte-Jeannin P, Biot B, Labalme A, Bernard JC, Chastang J, Kassai B, Plais MH, Moldovan F, Clerget-Darpoux F (2011) New disease gene location and high genetic heterogeneity in idiopathic scoliosis. Eur J Hum Genet 19(8):865-869

99. Miller NH, Justice CM, Marosy B, Doheny KF, Pugh E, Zhang J, Dietz HC 3rd, Wilson AF (2005) Identification of candidate regions for familial idiopathic scoliosis. Spine (Phila Pa 1976) 30(10):1181-1187

100. Miller NH, Marosy B, Justice CM, Novak SM, Tang EY, Boyce P, Pettengil J, Doheny KF, Pugh EW, Wilson AF (2006)
Linkage analysis of genetic loci for kyphoscoliosis on chromosomes 5p13, 13q13.3, and 13q32. Am J Med Genet A 140(10):1059-1068

101. Marosy B, Justice CM, Vu C, Zorn A, Nzegwu N, Wilson AF, Miller NH (2010) Identification of susceptibility loci for scoliosis in FIS families with triple curves. Am J Hum Genet A 152A(4):846-855

102. Clough M, Justice CM, Marosy B, Miller NH (2010) Males with familial idiopathic scoliosis: a distinct phenotypic subgroup. Spine (Phila Pa 1976) 35(2):162-168

103. Gao X, Gordon D, Zhang D, Browne R, Helms C, Gillum J, Weber S, Devroy S, Swaney S, Dobbs M, Morcuende J, Sheffield V, Lovett M, Bowcock A, Herring J, Wise C (2011) CHD7 gene polymorphisms are associated with susceptibility to idiopathic scoliosis. Am J Hum Genet 80(5):957-965

104. Sharma S, Gao X, Londono D, Devroy SE, Mauldin KN, Frankel JT, Brandon JM, Zhang D, Li QZ, Dobbs MB, Gurnett CA, Grant SF, Hakonarson H, Dormans JP, Herring JA, Gordon D, Wise CA (2011) Genome-wide association studies of adolescent idiopathic scoliosis suggest candidate susceptibility genes. Hum Mol Genet 20(7):1456-1466

105. Takahashi Y, Kou I, Takahashi A, Johnson TA, Kono K, Kawakami N, Uno K, Ito M, Minami S, Yanagida H, Taneichi H, Tsuji T, Suzuki T, Sudo H, Kotani T, Watanabe K, Chiba K, Hosono N, Kamatani N, Tsunoda T, Toyama Y, Kubo M, Matsumoto M, Ikegawa S (2011) A genome-wide association study identifies common variants near LBX1 associated with adolescent idiopathic scoliosis. Nat Genet. doi:10.1038/ng.974

106. Yimlamai D, Konnikova L, Moss LG, Jay DG (2005) The zebrafish down syndrome cell adhesion molecule is involved in cell movement during embryogenesis. Dev Biol 279(1):44-57 